\title{
Natureza de classe e características particulares do fascismo: contribuições de Gramsci para pensarmos o Brasil atual
}

Douglas Ribeiro Barboza'

\section{Resumo}

O artigo propõe resgatar as importantes análises de Antonio Gramsci sobre a forma por meio da qual o fascismo se impôs como alternativa para a sociedade italiana, desde uma perspectiva da luta econômica, política e ideológica travada pelas classes sociais e as suas frações. A compreensão gramsciana acerca da consolidação do fascismo como uma forma de Estado e uma forma de regime específico se constitui como um eixo central fundamental através do qual tentaremos desvelar, com as devidas mediações presentes na nossa particularidade histórica, o atual processo de fascistização da sociedade brasileira impulsionado com a ascensão de Bolsonaro ao poder.

Palavras-chave

Gramsci; Fascismo; Brasil.

Class nature and particular characteristics of fascism: Gramsci's contributions for thinking about the current Brazil

\begin{abstract}
The article proposes to rescue the important analyzes of Antonio Gramsci on the way in which fascism imposed itself as an alternative for Italian society, from a perspective of the economic, political and ideological struggle waged by social classes and their fractions. Gramscian understanding of the consolidation of fascism as a form of state and a form of specific regime constitutes itself as a central axis through which we will try to unveil, with the appropriate mediations present in our historical particularity, the current fascist process of Brazilian society boosted by Bolsonaro's rise to power.
\end{abstract}

Keywords

Gramsci; Fascism; Brazil.

Artigo recebido: março de 2021

Artigo aprovado: maio de 2021 


\section{Introdução}

Virginia Fontes (2019, s/d) sinaliza que existe uma enorme diferença entre "um presidente eleito com discurso fascista, a disseminação de práticas de cunho fascista e a institucionalização de um regime fascista", e que "não necessariamente o primeiro caso leva ao último". Todavia, a forma como se constrói o reordenamento do Estado brasileiro a partir da ascensão do governo Bolsonaro - por meio de um redesenho constitucional e institucional, realizado por intermédio de Emendas Constitucionais, Medidas Provisórias, Decretos, leis, além de subterfúgios administrativos - nos coloca a urgência e a prudência em desvendar quais os sinais que indicam os traços de fascistização que já vêm se conformando no cenário brasileiro.

Como resposta às insatisfações de vários setores da sociedade em relação ao agravamento da crise socioeconômica e à profunda crise do sistema de representação política, o Estado que se constrói a partir da eleição do ex-capitão do exército, num processo de "renovação-restauração", combina substantivas violações do liberalismo político com a preservação parcial de alguns de seus elementos formais, de forma a se adequar - de modo subordinado - a uma estrutura autocrática de poder que impede o livre exercício da soberania popular através de significativas restrições à competição política (MARTINS, 2018).

Constituindo-se como um governo de extrema-direita com tendências fascistizantes, o governo Bolsonaro se unifica em torno de três pilares, dialeticamente articulados para garantir a sua ascensão e consolidação: 1) o aprofundamento da escalada autocrática que se intensificou após o golpe institucional-jurídico-parlamentar-midiático de 2016; 2) a aplicação de um programa ultraliberal de eliminação radical de direitos sociais e trabalhistas que interessa a todas as frações do capital; 3) a defesa agressiva de "uma pauta sócio-cultural-educacional moralista, anticomunista, fundamentalista cristã, racista, machista, misógina e homofóbica, além de anticientífica e historicamente negacionista" (MACIEL, 2020, s/d). 
Considerando esse cenário, o presente artigo propõe resgatar as importantes análises do marxista italiano Antonio Gramsci - principalmente aquelas contidas no período anterior à sua prisão pelo regime de Mussolini - sobre a forma através da qual o fascismo se impôs como alternativa para a sociedade italiana, desde uma perspectiva da luta econômica, política e ideológica travada pelas classes sociais e as suas frações. A compreensão gramsciana do fascismo a partir das considerações de sua natureza de classe e suas características particulares, sua consolidação como uma forma de Estado e uma forma de regime específico, se constitui como um eixo central fundamental através do qual poderemos desvelar, com as devidas mediações presentes na nossa particularidade histórica, o atual processo de fascistização ${ }^{2}$ da sociedade brasileira impulsionado com a ascensão de Bolsonaro ao poder.

\section{Gramsci e as análises da ascensão do fascismo como uma nova ordem política e ideológica}

É importante destacar que as instituições políticas liberais sofreram uma acelerada e progressivamente catastrófica retirada entre os anos de 1917 e 1942, cuja vulnerabilidade se revelou pelo fato de que, “[...] sua forma de governo, a democracia representativa, em geral não era uma maneira convincente de governar Estados, e as condições da Era da Catástrofe raramente asseguraram as condições que a tornavam viável, quanto mais eficaz" (HOBSBAWM, 2008, p. 140).

Com a severidade do impacto da Grande Depressão (o qual deve ser julgado não somente pelos seus efeitos políticos de curto prazo, como também pela destruição de toda a esperança de restauração da economia, e da sociedade, do século XIX) e com a condenação à morte do velho liberalismo, tornava-se impossível e impensável, no abismo dos anos de 1929-1933, um retorno ao quadro do ano de 1913; o que fez emergir, na competição pela hegemonia intelectual-política, três opções: a primeira era o comunismo marxista, já que as previsões 
do próprio Marx pareciam concretizar-se tendo em vista que, enquanto o capitalismo liberal ocidental estagnava com a Crande Depressão, a União Soviética parecia estar imune aos seus efeitos e entrava numa industrialização ultrarrápida e maciça sob seus novos Planos Quinquenais - o que chamava a atenção de "observadores políticos e socioeconômicos" os quais, no afã de desvendarem a profundidade do sistema econômico do capitalismo ocidental, acabavam relegando a segundo plano a implacabilidade e brutalidade da coletivização e repressão em massa de Stalin, e o visível primitivismo da economia soviética. A segunda era "um capitalismo privado de sua crença na otimização de livres mercados, e reformado por uma espécie de casamento não oficial ou ligação permanente com a moderada social-democracia de movimentos trabalhistas não comunistas" (HOBSBAWM, 2008, p. 111). A terceira era o fascismo, o qual a Depressão “[...] transformou num movimento mundial, e, mais objetivamente, num perigo mundial" (HOBSBAWM, 2008, p. 112). Mesmo sob a falência generalizada do Estado e o enfraquecimento econômico na Europa daquele período, o sistema capitalista recebe "uma nova máscara de oxigênio" ao encontrar no fascismo uma nova ordem política e ideológica que não somente conseguiu manter-se no poder, como também despertou o entusiasmo de amplos setores populares.

Na sequência da crise de 1929, naquelas sociedades onde as ideias democráticas tinham raízes mais fundas e/ou o movimento operário e sindical não registrou derrotas, a nova forma de intervenção do Estado na economia não violentou a democracia política, tal como existia - é o que se consta na experiência da Europa Nórdica, da Inglaterra, da França e dos Estados Unidos. Nos países onde tais tradições eram débeis (Itália) e/ou onde o movimento operário foi mais golpeado (Alemanha), a intervenção do Estado deu-se conforme a natureza antidemocrática do capital, levada ao extremo pelos monopólios: com a supressão de todos os direitos e garantias ao trabalho e aos trabalhadores, instaurando-se o regime po- 
lítico mais adequado ao livre desenvolvimento dos monopólios - o fascismo (NETTO; BRAZ, 2007, p. 193-194).

Não podemos esquecer que a existência de movimentos extremistas da ultradireita já se dava antes mesmo da eclosão da Primeira Guerra Mundial. Mas apesar desses possuírem alguma influência no interior da direita política e em alguns círculos intelectuais, em lugar algum conseguiram alcançar o domínio ou o controle. Ao tentar explicar como a reação direitista conseguiu alcançar vitórias cruciais na forma do fascismo após o término da Primeira Guerra Mundial, Hobsbawm (2008) afırma que esta oportunidade só se tornou efetivamente realizável em decorrência de alguns fatores:

[...] o colapso dos velhos regimes, e com eles das velhas classes dominantes e seu maquinário de poder, influência e hegemonia [...]. As condições ideais para o triunfo da ultradireita alucinada era um Estado velho, com seus mecanismos dirigentes não mais funcionando; uma massa de cidadãos desencantados, desorientados e descontentes, não mais sabendo a quem ser leais; fortes movimentos socialistas ameaçando ou parecendo ameaçar com a revolução social, mas não de fato em posição de realizá-la; e uma inclinação do ressentimento nacionalista contra os tratados de paz de 1918-20. Essas eram as condições sob as quais as velhas elites governantes desamparadas sentiam-se tentadas a recorrer aos ultrarradicais, como fizeram os liberais italianos aos fascistas de Mussolini em 1920-2, e os alemães aos nacional-socialistas de Hitler em 1932-3. Essas, pelo mesmo princípio, foram as condições que transformaram movimentos da direita radical em poderosas forças organizadas e às vezes uniformizadas e paramilitares (squadristi; as tropas de assalto), ou, como na Alemanha durante a Grande Depressão, em maciços exércitos eleitorais (HOBSBAWM, 2008, p.129-130).

Se pensarmos no exemplo italiano, os Fasci di combattimento foram a primeira forma organizativa do movimento fascista, nascidos na Itália logo após a Primeira Guerra, quando, em 23 de março de 1919, 
Benito Mussolini reuniu nacionalistas e ex-combatentes para a formação de grupos armados que promoviam violentos ataques contra os organismos operários e socialistas, sobretudo nas zonas rurais ${ }^{3}$. Apesar de Mussolini proclamar a iniciativa como um impulso à criação de um "novo movimento", um "antipartido dos realizadores"4 - o que imprimiu um forte papel "ideológico" no início do movimento - esses grupos armados se tornaram a base do Partido Nacional Fascista que seria fundado no mesmo ano (1919).

Gramsci esforçou-se em demonstrar como o fascismo se associava com a profunda decomposição da sociedade italiana - que, por sua vez, vinha acompanhada por uma profunda decomposição do Estado. O Estado italiano, ainda frágil e inseguro nas suas articulações, só conseguia desbastar lentamente e com muita dificuldade o caráter "semibárbaro" e "extremamente violento" assumido pela luta de classe na Itália, e após a sua decomposição, passaram a pulular todas as pestilências desse cenário. Assim, ao apresentar-se como antipartido, o fascismo prometia a impunidade e abria as portas para todos os candidatos, o que permitiu que “[...] uma multidão informe cobrisse com um verniz de idealismo político vago e nebuloso o transbordamento selvagem das paixões, dos ódios, dos desejos" (GRAMSCI, 2004, II, p. 57).

O fascismo tornou-se assim uma expressão de nossos costumes, identificando-se com a psicologia bárbara e antissocial de alguns estratos do povo italiano, ainda não modificados por uma nova tradição, pela escola, pela convivência em um Estado bem organizado e bem administrado. Para compreender todo o significado destas afirmações, basta recordar que a Itália tinha o primado em homicídios e linchamentos; que a Itália é o país onde as mães educam os filhos com golpes de tamanco na cabeça, o país onde as jovens gerações são menos respeitadas e protegidas; que, em algumas regiões italianas, parecia natural, até poucos anos atrás, pôr uma focinheira nos vindimeiros para que não comessem as uvas; que, em algumas regiões, os proprietários trancavam a chave os seus trabalhadores nos estábulos, quando 
estes voltavam do trabalho, a fim de impedi-los de reunir-se e de frequentar as escolas noturnas (GRAMSCI, 2004, II, p. 57).

Coutinho (1999), citando as palavras de Alfonso Leonetti (companheiro de Gramsci em L'Ordine Nuovo), tende a concordar com a afirmação de que Gramsci tenha sido o primeiro (e o único de seu tempo) teórico marxista a tentar defınir o fascismo sob as considerações de sua natureza de classe e suas características particulares. De fato, já em 1921, Gramsci insiste na novidade essencial da reação fascista ao caracterizá-la como um movimento reacionário com base de massas, ou seja, um movimento "[...] apoiado na luta da pequena-burguesia para reconquistar o lugar político e econômico que vinha perdendo em função das transformações monopolistas que o capitalismo italiano experimentara sobretudo durante os anos de guerra." (COUTINHO, 1999, p. 50). No artigo “O povo dos macacos", Gramsci explica que, na última década do século XIX, inicia-se o processo de desagregação da pequena burguesia, pois essa começa a perder toda a sua importância devido ao desenvolvimento da grande indústria e do capital financeiro e passa a ser afastada progressivamente de qualquer função vital do terreno da produção. Torna-se, assim, uma classe puramente política e incrustada no instituto parlamentar, ou melhor, especializada no "cretinismo parlamentar", corrompendo o Parlamento "até a medula", deixando-o completamente à mercê do poder executivo e cada vez mais desprestigiado junto às massas populares. As greves e manifestações de 1914, que ficaram conhecidas como a "semana vermelha", foi a demonstração inaugural da percepção das massas populares de que o único meio que lhes restava para controlar e se opor aos arbítrios do poder administrativo era a "ação direta", a "pressão feita por fora", objetivando exercer realmente a soberania popular tendo em vista que esta não se expressava na Câmara dos Deputados. Com a completa decadência do Parlamento durante a guerra, a pequena burguesia - desprovida de qualquer esperança em reconquistar uma função produtiva, e que antes se pusera a serviço do 
poder governamental por meio da corrupção parlamentar - altera a sua "forma de prestação de serviços", e se torna antiparlamentarista, cultivando a ilusão de que poderia assumir a direção da classe operária e camponesa, e substituir a ideia socialista imanente às massas por uma "estranha e bizarra mistura ideológica de imperialismo nacionalista, de 'verdadeiro revolucionarismo', de 'sindicalismo nacional'" (GRAMSCI, 2004, II, p. 32). Mas suas atividades políticas foram frustradas, e como o poder de Estado oficial estava enfraquecido e esgotado pela guerra, essa pequena burguesia passou a se organizar e se agrupar em torno de senhores mais ricos e mais seguros, ou seja, os proprietários industriais e agrícolas que, para se defender contra os assaltos da classe revolucionária dos operários e camponeses pobres, passaram a financiar e manter uma organização privada a qual para camuflar sua real natureza - transvestiu-se de atitudes políticas "revolucionárias" e desagregou "a mais poderosa defesa da propriedade, ou seja, o Estado" (GRAMSCI, 2004, II, p. 33).

Esta atividade da pequena burguesia, convertida oficialmente em "fascismo", tem consequências para a organização do Estado. Depois de ter corrompido e arruinado a instituição parlamentar, a pequena burguesia corrompe e arruína também as demais instituições, os sustentáculos fundamentais do Estado: o exército, a polícia, a magistratura. [...] A pequena burguesia, mesmo nesta sua última encarnação política que é o "fascismo", revelou definitivamente sua verdadeira natureza de serva do capitalismo e da propriedade agrária, de agente da contrarrevolução. Mas revelou também que é fundamentalmente incapaz de desempenhar qualquer tarefa histórica [...]. A pequena burguesia [...] substitui, em escala cada vez maior, a "autoridade" da lei pela violência privada; exerce (e não pode agir de outro modo) essa violência de modo caótico, brutal, e faz com que se ergam contra o Estado, contra o capitalismo, segmentos cada [vez] mais amplos da população. (GRAMSCI, 2004, II, p. 33-34). 
Empenhado em captar as circunstâncias elementares e específicas que determinavam a posição política do fascismo, Gramsci desvela que os fascistas só puderam realizar suas atividades porque eram tolerados (e até mesmo apoiados) pelos aparelhos legais do Estado, em particular os organismos da segurança pública (delegados de polícia, guarda-régias, carabineiros) e da magistratura, que se tornaram seus "cúmplices morais e materiais" devido à consciência de que a manutenção de sua impunidade e o êxito de suas carreiras se ligavam estreitamente aos destinos da organização fascista (GRAMSCI, 2004, II, p. 66). Entretanto, percebia também que essa nova reação assumia táticas de acesso ao poder bastante diferenciadas daquelas utilizadas pela velha reação conservadora, pois apesar de contarem com apoio dos organismos do Estado para utilizarem toda a força que eles dispunham para se conservarem impunes e para alcançarem a finalidade máxima de todo o movimento - isto é, a posse do governo político -, os fascistas atuavam a partir "de baixo", de movimentos situados à margem das instituições estatais, o que trazia a necessidade - conforme deixou claro nas páginas do artigo "Os arditi del popolo" - de analisá-los em sua realidade objetiva, excluindo qualquer esquema preestabelecido e qualquer plano político abstrato, ou seja, encarar o fascismo “[...] como uma proliferação espontânea de energias reacionárias que se agregam, se desagregam e se reagrupam, seguindo os líderes oficiais somente quando as palavras de ordem deles correspondem à íntima natureza do movimento" (GRAMSCI, 2004, II, p. 74).

Ao examinar o processo de desenvolvimento do movimento fascista, Gramsci pôde indicar a existência de duas orientações no seu interior (uma voltada para a fiel permanência aos métodos de ação violenta do terrorismo, e outra que concebia a possibilidade de uma ação parlamentar) que eram decorrentes da própria gênese do movimento: por um lado, os Fasci di combattimento obtiveram apoio dos capitalistas e das autoridades devido ao seu caráter de oposição aberta ao movimento socialista ; por outro, a afırmação dos Fasci di combatti- 
mento em consonância com a necessidade de criação, por parte dos grandes latifundiários, de uma tropa de choque contra os movimentos camponeses, permitiu que essa tropa assumisse a mesma etiqueta dos Fasci, conferindo-Ihes, posteriormente, "a mesma característica de guarda branca do capitalismo contra os órgãos de classe do proletariado" (GRAMSCI, 2004, II, p. 80). Revela-se, assim, a capacidade de uma hábil e pragmática combinação tática entre o "legalismo" e o "subversivismo", sob a qual o fervor da ofensiva armada e as contingentes razões que unificavam as fileiras antiproletárias impediam o agravamento do dissídio entre as duas orientações, as quais se confıguravam da seguinte forma:

[...] por um lado, os núcleos urbanos, pequenos-burgueses, constituídos predominantemente por parlamentares e colaboracionistas, e, por outro, os núcleos rurais, formados por grandes e médios proprietários agrícolas e pelos colonos, interessados na luta contra os camponeses pobres e suas organizações. Esses núcleos rurais são decididamente antissindicais, reacionários; confiam mais na ação armada direta do que na autoridade do Estado e na eficácia do Parlamento. (GRAMSCI, 2004, II, p. 80-81).

Enquanto se acreditava que o fascismo era uma experiência limitada aos países industrialmente subdesenvolvidos, uma expressão de uma economia agrária, Gramsci indicava a capacidade de expansão do fascismo até o plano internacional, tornando-o uma ameaça, um cataclismo possível à escala de "todos os países da Europa Ocidental" caso as condições econômicas gerais se mantivessem como se apresentavam naquele momento ${ }^{5}$. À escala internacional, o fascismo representava a tentativa de resolver os problemas da produção e da troca através da força militar, e a Espanha configurava-se como um exemplo desse processo. De acordo com as suas formulações expostas no artigo "Itália e Espanha”, publicado em L'Ordine Nuovo a 11 de março de 1921, a fase pela qual a Itália atravessava naquele momento, “do armamento das classes médias e da introdução, na luta de classes, 
dos métodos militares do assalto e dos golpes de surpresa", já havia sido experimentado pela Espanha entre os anos de 1918-1919, quando os fasci antibolcheviques (os somaten ${ }^{6}$ ) ampliaram as suas bases e seguiram a mesma tática dos fascistas italianos:

[...] agressão aos líderes sindicais, violenta oposição às greves, terrorismo contra as massas, oposição à toda forma de organização, ajuda à polícia regular nas repressões e nas prisões, ajuda aos fura-greves nas agitações grevistas e nos locautes. Há três anos a Espanha se debate nesta crise: a liberdade pública é suspensa a cada quinze dias, a liberdade pessoal tornou-se um mito, os sindicatos operários funcionam em grande parte clandestinamente, a massa operária faminta e exasperada, a grande massa popular está reduzida a condições de selvageria e de barbárie indescritiveis. E a crise se acentua. Chegou-se agora ao atentado individual. (GRAMSCI, 2004, II, p. 47-48).

Era preciso aprender o que a experiência histórica não cansava de ensinar. Gramsci não somente analisava a base social do fascismo como também mostrava a envergadura do combate político que se necessitava travar para impedir que um golpe de Estado fascista - a "tirania do Estado-Maior, dos latifundiários e dos banqueiros" - viesse a pesar sobre o povo italiano (GRAMSCI, 2004, II, p. 66). Em outras palavras, Gramsci percebera e denunciara que o golpe de Estado fascista era um espectro ameaçador que, desde o início, pesava sobre a legislatura italiana. Os socialistas italianos não pensavam acerca dos meios que era preciso pôr em prática para que se pudesse passar a contraofensiva revolucionária, pois ainda permaneciam com uma certa "confiança ingênua" nas possibilidades da democracia parlamentar. De fato, ainda existia um Parlamento; ainda existia um governo que era escolhido e controlado por este Parlamento; e as garantias institucionais ainda não tinham sido abolidas por nenhuma lei excepcional. Mas se ainda não se configurava o golpe de Estado em sua plena execução, não se poderia negar que uma plena atmosfera de um golpe de Estado 
já era vivida pela Itália, afınal de contas, "como se poderia explicar o significado da situação de inteiras províncias e regiões onde é o fascismo que governa e não mais a autoridade ofıcial?". A pena de morte não terá sido restaurada, "[...] retomado o uso do porrete? Pode-se negar que tais formas de punição sejam hoje administradas por organismos extralegais?" (GRAMSCI, 2004, II, p. 77). Não era impossível prever que esta situação de existência de um duplo aparelho punitivo e repressivo na Itália - o fascismo e o Estado burguês - teria vida curta, pois a classe dominante buscaria, em certo momento, amalgamar também oficialmente esses dois aparelhos, por meio de um golpe de força dirigido contra os organismos centrais de governo, de forma que viesse a quebrar as resistências opostas pela tradição do funcionamento estatal.

As primeiras formulações gramscianas de que o fascismo seria apenas um instrumento (consciente ou inconscientemente) de preparação de uma iminente fase social-democrata na Itália decorre, conforme nos esclarece Coutinho (1999), de uma ausência nas reflexões gramscianas de uma avaliação da possibilidade de um regime fascista, isto é, de uma concepção do fascismo não apenas como “[...] um movimento reacionário de novo tipo, capaz de fornecer base de massa aos setores economicamente dominantes, mas também um eventual regime reacionário do tipo novo", ou seja, um regime que divergia radicalmente das velhas ditaduras conservadoras de tipo semiparlamentar ou militar, pois se configura como "[...] uma ditadura do capital financeiro, que se apóia sobre uma ampla rede de organizações de massa, sobre o consenso organizado da maioria da população" (COUTINHO, 1999, p. 51)7. Todavia, a chegada dos fascistas ao governo - em 28 de outubro de $1922^{8}$ - influenciou para um enriquecimento da definição de Gramsci acerca do fascismo, na qual já se percebe alguns elementos de teorização do mesmo como um regime.

Numa carta enviada de Moscou a Palmiro Togliatti, em agosto de 1923, Gramsci declara que os movimentos emergidos nos últimos trinta anos na Itália se caracterizaram como "um aparelho para selecionar 
novos elementos dirigentes do Estado burguês" e que o fascismo se apresentava como o "último e mais decisivo desses movimentos, que busca absorver todo o novo estrato social que se formou, dissolvendo os vínculos entre os líderes e a massa". Entretanto, ressalta que o fascismo tenderia a se tornar "um movimento integral, de uma nova classe, que jamais foi independente no Estado italiano: a burguesia agrária, aliada aos grandes proprietários contra os camponeses e os operários" (GRAMSCI, 2004, II, p. 137 e 138). Posteriormente, Gramsci afirma que Mussolini não pôde se tornar líder do proletariado, mas se tornou um "ditador da burguesia", que conquistou o governo e o manteve por meio da mais violenta e arbitrária repressão. Mussolini não precisou organizar uma classe, mas somente o pessoal de uma administração, desmontando algumas engrenagens do Estado não por necessidade, mas para conferir e aprender como eram feitas e como deveria usá-las (GRAMSCI, 2004, II, p. 240).

Em setembro do mesmo ano, afirma que o fato característico do fascismo - e de cunho inédito na história - "[...] é ter conseguido constituir uma organização de massa da pequena burguesia", ou seja, sua originalidade consiste "[...] em ter encontrado a forma adequada de organização para uma classe social que sempre foi incapaz de se unificar e de ter uma ideologia unitária: esta forma de organização é a do exército em

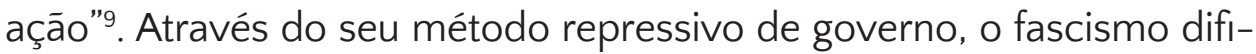
cultou extremamente - ou, pode-se até dizer que impediu quase completamente - as manifestações políticas da crise geral do capitalismo, iniciada tanto na Itália quanto no resto do mundo em decorrência da Primeira Grande Guerra; porém não signifıcou a sua interrupção, nem mesmo sequer uma retomada e um desenvolvimento da economia nacional. Em resumo, "[...] a crise geral do sistema capitalista não foi freada pelo regime fascista." (GRAMSCI, 2004, II, p. 262 e 265, grifo nosso).

No regime fascista, as possibilidades de existência do povo italiano diminuíram. Verificou-se uma redução do aparelho pro- 
dutivo[...]. O aparelho industrial reduzido só pôde se salvar do completo esfacelamento por causa de uma queda de vida da classe operária, provocada pela diminuição dos salários, pelo aumento da jornada de trabalho, pela elevação do custo de vida. Isso provocou [...] um empobrecimento das forças produtivas humanas, que eram uma das maiores riquezas nacionais. (GRAMSCI, 2004, II, p. 265).

Gramsci ressalta que o fascismo - nas suas origens, organização e trajetória - é favorecido por todos os velhos grupos dirigentes, mais particularmente pelos latifundiários que se sentem mais ameaçados pela pressão das plebes rurais. Isso se dá pelo fato de que o fascismo se inscreve, no quadro da política tradicional das classes dirigentes italianas e na luta capitalista contra a classe operária, como um movimento de reação armada cujo objetivo é a imobilização da classe trabalhadora através da sua desagregação e desmobilização. Mas, socialmente, o fascismo encontra apoio na pequena burguesia urbana e numa nova burguesia agrária despontada com a transformação da propriedade rural ocorrida em certas regiões da Itália, o que proporciona ao fascismo - conjuntamente com o fato desse ter encontrado uma unidade ideológica e organizativa nas formações militares que exaltam a tradição guerreira (o arditismo ${ }^{10}$ ) - a possibilidade de conceber e pôr em prática um plano de conquista do Estado, de forma antagônica às velhas camadas dirigentes. (GRAMSCI, 2004, II, p. 331332). Por terem originariamente uma mentalidade em comum de "capitalismo nascente", essas novas camadas que se agrupam em torno do fascismo conseguem efetivar uma luta contra os políticos do passado justificando-a como uma "construção ideológica contraposta às teorias tradicionais do Estado e de suas relações com os cidadãos".

Não se podia eliminar o conturbado cenário que se desenvolvia nesse período de maturação conceitual gramsciana. A atividade dos partidos antifascistas já vinha sendo há muito sufocada, com a constante perseguição e vigilância dos deputados comunistas efetuada 
desde o final de 1924. Conforme nos esclarece Simionatto (2004), o fascismo, já em 1926, efetivamente passava a se conformar como um regime totalitário, sob o qual Mussolini valia-se do auxílio dos bancos, da indústria e da agricultura para garantir os privilégios econômicos do bloco industrial-agrário (que alcançara um elevado grau de unificação econômica e política) além de protegê-los contra o proletariado da cidade e do campo. Em detrimento de amplos setores do setor agrícola (especialmente os camponeses), o fascismo solidificou progressivamente as posições da indústria da Itália, enquanto reforçou as relações capitalistas no campo sem sequer indicar qualquer possibilidade de solução das problemáticas questões da terra. A corrupção e a indiferença com os graves problemas que solapavam o povo italiano eram camufladas pela grande investida ideológica do fascismo não somente na área da política como também nas artes, na literatura, na vida de todos os grupos e classes sociais.

Guiado por um pragmatismo radical e apresentando uma proposta modernizadora, o fascismo defendia uma política favorável à crescente concentração de capital, mostrando-se conservador na sua face social e política, antioperário, antidemocrático e corporativista. A pátria apresentava-se como o valor máximo e supremo; o mito da nação tornara-se característica essencial do fascismo, independentemente dos países onde ele se manifestava. (SIMIONATTO, 2004, p. 30-31).

Neste quadro, o processo de maturação dos escritos gramscianos é bruscamente interrompido quando, em novembro de 1926, Gramsci é preso juntamente com outros deputados comunistas - apesar da proteção conferida pelas imunidades parlamentares - e recolhido ao cárcere em isolamento absoluto e rigoroso, em decorrência das "medidas excepcionais" adotadas pelo regime fascista depois de um obscuro atentado contra Mussolini ocorrido dias antes em Bolonha". Gramsci, durante os anos do cárcere, afirmava que o movimento fascista seria, no século XX, "o movimento correspondente ao do liberalismo mo- 
derado e conservador" protagonizado no século anterior. (GRAMSCI, 200, v.1, p. 299). A Europa era assolada por uma severa "crise orgânica", e a "moderna" solução dos setores dominantes conformava-se na direção de uma reafirmação das tendências autoritárias e uma política populista mistificadora que visava despolitizar os conflitos sociais, de forma que as tentativas das classes trabalhadoras em recriar a sociedade a partir de suas livres e conscientes organizações fossem, mais uma vez, frustradas. Com o intuito de aglutinar harmonicamente as forças disseminadas na sociedade civil, o Partido Fascista conduzia, através de hábeis manobras demagógicas, uma mediação entre massas e Estado (mecânica essa que era o elemento central da moderna política autoritária), ou melhor, efetuava uma progressiva assimilação das massas - simplesmente de "manobra" e constantemente bombardeada com messiânicos sermões prometedores de um fabuloso futuro no qual seriam automaticamente sanadas todas as contradições e misérias presentes - aos "mais elevados interesses do Estado"12.

Não obstante da sua retirada de circulação no campo da atividade política, a condenação de Gramsci não conseguiu realizar o desejo do promotor fascista em "evitar com que aquele cérebro continuasse funcionando", pois, superando as duras condições do cárcere, o marxista sardo obstinou-se na batalha antifascista e pró-liberdade do povo italiano, deixando, ao fenecer, uma obra de grande importância formada pelas notas redigidas na prisão, de 1929 a 1935 (totalizando um conjunto de quase 2500 páginas), que ficou posteriormente conhecida como os Cadernos do cárcere, nas quais não somente melhor desenvolveu aqueles conceitos básicos já construídos e amadurecidos, como também enriqueceu com novos conceitos as suas reflexões acerca dos complexos acontecimentos referentes à época em que exerceu suas atividades políticas.

\section{Considerações finais}

Para complementar as argumentações gramscianas aqui expostas, cabe-nos retomar as formulações de Poulantzas (1972) o qual reforça 
que, para analisarmos o fascismo em sua substância é preciso situá-lo como expressão de uma determinada etapa do capitalismo (Imperialismo). Ele é decorrente da emergência de uma situação específica de crise política - caracterizada pela incapacidade de uma classe ou fração conquistar a hegemonia no interior do bloco no poder e sob o conjunto da formação social -, crise essa que pode ser acompanhada por uma crise econômica e ideológica. Além disso, pode ocorrer uma ampliação da incapacidade de os partidos políticos representarem as classes e frações de classes. Esse cenário ara o terreno para a instauração de uma forma específica de Estado e regime, fascista, de caráter ditatorial, acompanhada de profundas rupturas do sistema institucional, os quais podem emergir sob diferentes composições do bloco no poder que podem variar conforme a própria conjuntura da luta de classes, do estágio de acumulação do capitalismo mundial e das particularidades de cada formação social específica.

Com esses traços, poderíamos concluir que a partir do momento em que as crises políticas e de representação se reproduzem no presente, a questão do fascismo se torna atual, tornando-se possível o seu ressurgimento a partir de diferentes formas que não se construiriam como cópias exatas da sua experiência "clássica".

Seguindo a linha de Poulantzas, e no esforço de compreender a possibilidade neofascista na atualidade - mais especificamente as condições de sua emergência e as características desse processo no cenário brasileiro atual - Boito Jr. (2019) estabelece uma defınição do movimento fascista, sua composição de classes e os interesses que mobilizam:

O fascismo é um movimento reacionário de massa enraizado em classes intermediárias das formações sociais capitalistas. Ele é movido por um discurso superficialmente crítico - e, ao mesmo tempo, profundamente conservador - sobre a economia capitalista e a democracia burguesa. A sua ideologia é heterogênea, pouco sistemática, e nela se destacam a designação da esquerda como o inimigo a ser destruído, o culto da violên- 
cia, um nacionalismo autoritário e conservador e a politização do racismo e do machismo. É um movimento que chega ao poder, não como representante de tais classes intermediárias, mas, sim, após ter sido politicamente confiscado pela burguesia ou uma de suas frações com o objetivo de, apoiada nele, superar uma crise política e implantar um governo antidemocrático, antioperário e antipopular. (BOITO JR., 2019, p, 4).

O autor afırma que essa dinâmica prevaleceu tanto no fascismo clássico quanto no neofascismo brasileiro. Todavia, considerando que um movimento fascista, movido por uma ideologia fascista, pode chegar ao governo sem que necessariamente venha a implantar uma ditadura fascista, o que aconteceu no Brasil é que atualmente temos a “ideologia neofascista, o movimento neofascista, um governo no qual os neofascistas disputam a hegemonia com o grupo militar - esse último apegado a um autoritarismo mais propenso a outro tipo de ditadura - mas não temos um regime político fascista - o que temos é uma democracia burguesa deteriorada e em crise" (BOITO JR., 2019, p. 4).

O bolsonarismo que alcança a posição de governo no país, como uma espécie de movimento neofascista, emerge a partir de um terreno de forte crise econômica, política e institucional que gerou um cenário de altos níveis de desemprego, insegurança, instabilidade, desmoralização política e uma profunda crise de representatividade dos partidos tradicionais com signifıcativa participação na vida política nacional. A crise política do Bloco no poder que desaguou, nos marcos institucionais, no impeachment da presidente Dilma Rousseff e no instável governo Temer, contou com mobilizações massivas da classe média alta, imediatamente identificada com as pautas contrárias à corrupção, à criminalidade, à "velha política", com uma crítica "antissistêmica" a partir do viés antipolítico, anticomunista e conservador-cristão.

Assentada no mantra do combate à corrupção e à ineficiência do Estado combinado com a defesa da ditadura militar e o ataque odioso ao PT e todos os setores da esquerda; impulsionando, sob a vestimenta do 
fundamentalismo religioso cristão, uma pauta sócio-cultural-educacional moralista, com a disseminação de práticas punitivistas, de ataques aos direitos humanos, de discursos racistas, machistas, misóginos e lgbtfóbicos; e se valendo de uma forte manipulação da informação e de um culto ao negacionismo histórico e ao desprezo a qualquer pensamento científico e progressista, a extrema-direita neofascista tomou o Planalto sob a figura de Jair Bolsonaro. Este militar reformado que se colocava como representante da "nova política" (mas representava a continuidade das práticas mais vis dos corredores da pequena política) não somente expressa a síntese de todas as variadas forças do campo político conservador presentes em nosso terreno histórico e alçadas ao poder a partir impeachment de Dilma Rousseff, como também é o motor de radicalização dos componentes autocráticos e fascista presente nas mesmas. Junto com seu fiel escudeiro Paulo Guedes, aplica o programa ultraliberal e eleva a um novo patamar a escalada autocrática aprofundada após o golpe de 2016, implementando um conjunto de políticas que atendem, sobretudo, aos interesses da grande burguesia financeira internacional e a burguesia brasileira a ela associada.

Neste sentido, precisamos recuperar urgentemente os ensinamentos do grande marxista italiano. Gramsci, à sua época, compreendera o fascismo como uma forma moderna de "revolução passiva", ou seja, como expressão de reformismo que o capitalismo havia elaborado para se reorganizar no Ocidente (GRAMSCI, 2002, v. 4). Também explicitou que a principal preocupação do moderantismo conservador da revolução passiva é “[...] o temor pânico [...] de qualquer intervenção ativa das grandes massas populares como fator de progresso histórico (GRAMSCI, 2002, v.1, p. 291). Mas, ao mesmo tempo, lutou incessantemente para demonstrar que o perigo do fascismo é absoluto e que, nesses marcos, é necessário organizar um contra-ataque perante a ofensiva fascista, isto é, "lançar a palavra de ordem da insurreição, conduzir o povo em armas até a liberdade, garantida pelo Estado operário." (GRAMSCI, 2004, II, p. 67). 


\section{Referências}

BOITO JR. A. O neofascismo no Brasil. Boletim LIERI. n. 1, p. 1-11. Mai. 2019.

COUTINHO, C. N. Gramsci: um estudo sobre seu pensamento político. Rio de Janeiro: Campus, 1999

FONTES, Virginia. O protofascismo - arranjo institucional e policialização da existência. Revista eletrônica Marxismo 21, 2019. Disponível em: https:// marxismo21.org/wp-content/uploads/2017/05/Virg\%C3\%ADnia-Fontes-O-protofascismo-\%E2\%80\%93-arranjo-institucional-e-policializa\%C3\%A7\%C3\%A3o-da-exist\%C3\%AAncia.pdf . Acesso em: 18 mar 2021.

GRAMSCI, A. Cadernos do Cárcere. Rio de Janeiro: Civilização Brasileira, 2002. 6 v. GRAMSCI, A. Escritos políticos. Rio de Janeiro: Civilização Brasileira, 2004. 2 v. HOBSBAWM, E. J. Era dos extremos: O breve século XX. 1914-1991. 2. ed. São Paulo: Companhia das Letras, 2008.

MACIEL, D. Governo Bolsonaro, ameaça fascista e luta socialista. Revista eletrônica Marxismo 21, 2019. Disponivel em: https://marxismo21.org/wp-content/uploads/2017/05/David-Maciel-Governo-Bolsonaro-amea\%C3\%A7a-fascista-e-luta-socialista.pdf. acesso em: 18 mar. 2021.

MACCIOCCHI, M. A. Gramsci e a questão do fascismo. In: MACCIOCCHI, M. A. Elementos para uma análise do fascismo. [S.I.]: Bertrand, 1977.

MARTINS, C. E. Escalada fascista no Brasil: as tarefas do campo popular e democrático. Blog da Boitempo. 09 out. 2018. Disponível em: https://blogdaboitempo.com.br/2018/10/09/a-escalada-fascista-no-brasil-as-tarefas-do-campo-popular-e-democratico/ . Acesso em: 18 mar. 2021.

NETTO, J. P.; BRAZ, M. Economia política: uma introdução crítica. 3. ed. São Paulo: Cortez, 2007.

POULANTZAS, N. Fascismo e Ditadura. Porto: Portucalense Editora, 1972.

SEMERARO, G. Cramsci e a sociedade civil: cultura e educação para a democracia. 2. ed. Petrópolis, RJ: Vozes, 2001.

SIMIONATTO, I. Gramsci: sua teoria, incidência no Brasil, influência no Serviço Social. 3. ed. São Paulo: Cortez, 2004. 


\section{Notas}

1 Doutor em Serviço Social pela Universidade do Estado do Rio de Janeiro (PPCSS/ UERJ), Professor do Departamento de Serviço Social da Universidade Federal Fluminense (UFF-Niterói) e docente permanente do PPCSSDR-UFF/Niterói. Brasil. ORCID ID: https://orcid.org/0000-0001-8151-8511. E-mail: douglasrb@id.uff.br

2 Sobre processos de fascistização, ver Poulantzas (1972).

3 Hobsbawm (2008) nos esclarece que não se pode subestimar que, para uma importante camada de soldados e jovens nacionalistas (oriundos, em sua maioria, da classe média e média baixa), o impacto do término da Primeira Grande Guerra trouxe o ressentimento de que a sua oportunidade de heroísmo havia sido perdida. Se a guerra mostrou-se como uma máquina que brutalizou o mundo, esses homens tiveram nela a oportunidade de se satisfazerem através da possibilidade de liberação da sua brutalidade escondida, e, não por um mero acaso, os denominados "soldados da linha de frente" (frontsoldat) acabaram desempenhando um papel de grande importância na mitologia dos movimentos da direita radical e proporcionando um substancial corpo dos primeiros esquadrões de ultranacionalistas violentos - os squadristi italianos e freikorps alemãs. A constatação de que cinquenta e sete por cento dos primeiros fascistas italianos eram ex-soldados nos mostra o quanto esses "Rambos" da época tornaram-se os recrutas naturais da direita radical (Ibidem, p. 128). (HOBSBAWM, 2008, p.128-129).

4 Mussolini apud Gramsci (2004, II, p. 444-445, nota de fim de página).

5 "As forças produtivas foram arruinadas e dilapidadas na guerra imperialista. Vinte milhões de homens foram mortos na flor da idade e da energia; outros vinte milhões tornaram-se inválidos. Os milhares e milhares de laços que uniam os diversos mercados mundiais foram violentamente rompidos. As relações entre cidade e campo, entre metrópoles e colônias, foram subvertidas. As correntes de emigração, que restabeleciam periodicamente os desequilíbrios entre o excesso de produção e as potencialidades dos meios produtivos em cada nação, foram profundamente abaladas e já não funcionam normalmente. Criou-se uma unidade e simultaneidade de crises nacionais, que fazem com que a crise geral seja extremamente aguda e incontornável. Mas existe, em todos os países, um estrato da população - a pequena e a média-burguesia - que considera ser possível resolver esses gigantescos problemas com metralhadoras e pistolas; E é esse estrato que alimenta o fascismo, que fornece seus efetivos." (CRAMSCI, 2004, II, p. 46-47).

6 Os somaten eram, originariamente, uma milícia municipal surgida na Espanha no século XI, e que num primeiro momento chegaram a desempenhar uma função democrática e até mesmo revolucionária, sobretudo durante a guerra contra Napoleão. Entretanto, no período em que Gramsci redige o seu artigo, somaten havia se tornado a designação para grupos espanhóis que se assemelhavam às 
tropas de assalto do Partido Fascista na Itália (que, neste caso, assumiram o nome Fasci - literalmente, "feixos" - palavra herdada de um dos símbolos militares da antiga República Romana).

7 Esta ausência é compreensível, conforme complementa Coutinho, ao se levar em conta "[...] que o fascismo ainda não chegara ao poder, e muito menos ao poder absoluto, o que só ocorrerá em 1926" (Ibidem).

8 Nas palavras do próprio Cramsci, "a marcha sobre Roma foi a expressão coreográfica de um processo molecular por meio do qual as forças efetivas do Estado burguês (exército, magistratura, polícia, jornais, Vaticano, maçonaria, Corte, etc.) passaram para o lado do fascismo." (CRAMSCI, 2004, II, p. 273). Sobre este processo, ver MACCIOCCHI (1977)

9 "[...] o fascismo lutou contra o proletariado e chegou ao poder explorando e organizando a inconsciência e o espírito de rebanho da pequena burguesia embriagada de ódio contra a classe operária, que conseguia - graças à força de sua organização - atenuar os efeitos da crise capitalista que a atingiam [...]." (GRAMSCl, 2004, II, p. 262-263).

10 Esse termo se refere aos grupos de assalto, formados basicamente por voluntários, que tiveram um papel de destaque durante a Primeira Guerra Mundial, e que após o término do conflito bélico formaram uma Associação de arditi (que significa, literalmente, "os que têm ousadia, audácia, coragem"), composta por ex-combatentes que alimentavam uma ideologia fortemente nacionalista e que, posteriormente, em sua grande parte, passaram a integrar as tropas de choque do fascismo (Fasci di combattimento) utilizadas nas guerrilhas contra os trabalhadores.

11 Nas palavras de Coutinho (1999, p. 77), Cramsci não conseguiu escapar a tempo do "golpe no interior do golpe" desfechado por Mussolini, no qual "[...] suprimiu, em final de 1926, as últimas e precaríssimas liberdades democráticas que ainda vigoravam na Itália durante a primeira fase de seu governo. O processo de crescente fascistização do Estado chegava a seu desfecho: instalava-se agora um sistema totalitário (Gramsci), no qual o Parlamento foi suprimido, todos os partidos não fascistas dissolvidos, toda a população enquadrada numa rede capilar de organizações fascistas de massa (sindicatos, associações juvenis, femininas, infantis, recreativas, etc.).".

12 Conforme destaca Semeraro (2001, p. 34-35), "Esbanjando retórica sobre a grandeza da pátria e a moralização dos costumes, Mussolini conseguiu aglutinar as paixões das massas e o fanatismo de seus seguidores em torno da repulsa a tudo o que parecia responsável pela crise e debilidade nacional: incapacidade dos governantes, inconsistência das políticas liberais, movimentação das organizações operárias, ameaça do perigo comunista. Sem projeto concreto específico, a onda fascista foi crescendo ao explorar os sentimentos de descontentamento geral e transformou-se em coletor de todas as correntes antidemocráticas [...]." 